\title{
Public Schools and Private Schools in Ethiopia: Partners in National Development?
}

\author{
Teshome Nekatibeb Begna \\ Center for Comparative Education and Policy Studies, Addis Ababa University, Ethiopia
}

\begin{abstract}
Ethiopia has given emphasis to the expansion of primary education to enhance the socio-economic transformation of its population. Because of its limitations to fund the expansion of the sector, however, the government has introduced privatization as means to shift costs to users. Due to this, a dual system of education has grown in the nation. To ensure that both types of schools provide equivalent education, the government has introduced a primary school measurement standard. So far, no study has been carried out whether these standards are met and if schools provide equitable education. The purpose of this study was to fill this gap and analyze whether public and private primary schools provide equitable education in Ethiopia. A multi-method research approach with a case study and survey perspectives was adopted to conduct the study. A total of 68 public and private schools were purposefully selected and 1,260 respondents participated in the study. Findings indicate that learning in private schools leads to more academic achievements than in public schools. Moreover, public schools don't meet the minimum quality standards required by the government. It was indicated that private schools differ from public schools for making rigorous selection of students, admitting students with appropriate age from families having higher levels of education. As compared to public schools, private schools provide more access to classrooms and teachers, attractive work environment, sufficient facilities, qualified teachers, enriched curricula and a school management focused on results. From these findings, it was implied that the government needs to upgrade public schools, keep an eye on irregular practices in private schools and control the mutation of public schools into private institutions.
\end{abstract}

Keywords: Public schools, private schools, national development, learning achievement, school effectiveness

\section{BACKGROUND}

The government of Ethiopia issued two policy documents titled the 'Education and Training Policy' and the 'Education Sector Strategy' in 1994 in which it committed itself to achieve universal primary education by 2015 . The government made it clear that it would play a major role in the development of education by increasing the financing of the educational system through budget allocation. At the same time, it has recognized that it won't be able to bear the costs of educational expansion alone. Thus, it proposed privatization as an option in the strategy document as follows:

The participation of the community will be encouraged and enhanced in building schools and provision of furniture on a voluntary self-help basis. Private sector participation shall be promoted in the provision of and assistance of educational service. Different cost sharing mechanisms shall be studied and introduced particularly for beneficiaries of higher education (MOE: 1994a:13).

After two decades of educational reforms following the above guideline, Ethiopia has developed a dual system of education all along from preprimary to higher education. One is the public or government sector while the other is the non-government or private sector. There are different expectations from the emerging private sector. For the government, privatization would bring about expanded access towards the achievement of universal primary education. Simultaneously, it would shift away some of the financial burdens to users. For affording parents, opportunities for learning alone are not sufficient for their children and they require good quality education. This would mean qualified teachers, adequate facilities and learning materials, good learning environments, higher achievements in national examinations. They also need safe environments and equal treatments, particularly for their female children. Such parents are ready to pay a certain amount of fees in return for the services they are provided. As consumers, there is no doubt that they would like to also be consulted about matters pertaining to their children's learning. 


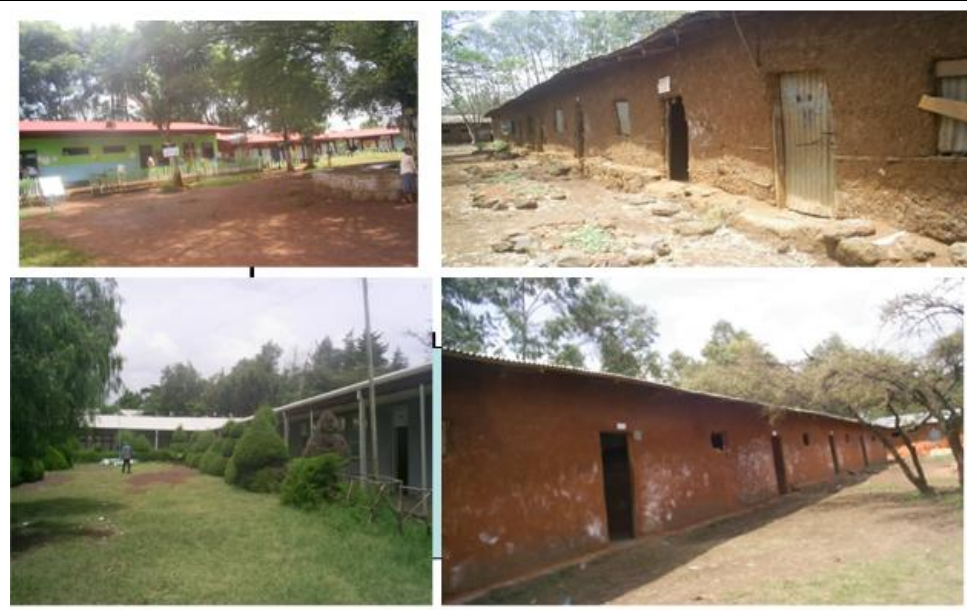

Private Public

Theoretically, demands on the public schools are similar to the private schools, but with minimum or no fees paid. To this end, the Ministry of Education (MOE) (2009) has provided a guideline to standardize the operations of schools in Ethiopia. The purpose of the standard is to ensure equivalence of learning conditions among all schools irrespective of whether they are urban or rural. It also applies to both private and public schools.

Ethiopia remained a predominantly rural country and about $86 \%$ of its population lives in rural areas. Thus, most primary schools are located in rural areas and MOE (2012/13) reported that $81 \%$ of primary school students are rural. Over the past two decades, the government has issued several policy and planning documents having common visions to end poverty and move the country into a middle-income economy by 2025 (AAU, 2008). The first five year plan (2010/11-2014/15), commonly known as the Growth and Transformation Plan (GTP), puts both rural, agricultural and industrial transformation as important dimensions of the development strategy. According to Freeman and Mohamedbhai (2011:1), the GTP sets forth the national priorities as "...agriculture and rural development, industry, infrastructure, social and human development, good governance and democratization."

While the GTP is strikingly ambitious, it is within this context that the revolutionary expansion of education, improvement of its quality, equity and relevance draw their meaning. It is intended to serve all sectors by producing more highly qualified workforce that is demanded by industry, particularly the growing manufacturing industry at all levels (Ministry of Finance and Economic Development, 2012). The goal is to provide ample opportunities for learning and produce efficient and effective, knowledge based and innovative citizens who would contribute to the transformation process. Given the dual system, however, no study has been carried out how these different schools partner to equally provide services towards these goals under unequal circumstances. Thus, the question is to what extent and how these systems contribute to the production of highly skilled citizens of equivalent quality in the transformation process. The purpose of this study is to explore the characteristics of public and private primary schools in maintaining the standards for quality and equity of education in the transformation process in Ethiopia. Our research questions revolve around three pillars: Do students in private and public school achieve equivalent academic results? Do private and public schools provide equivalent opportunities to students in terms of gender, parental background, selection and admission? Do private and public schools work under similar conditions?

\section{OBJECTIVES AND SignifiCANCE OF THE STUDY}

The overall objective of the study is to analyze the equity in standards of public and private primary schools in the national development process in Ethiopia. The specific objectives of the study are the following:

- To analyze student achievement both in private and public schools using the results of regional primary school leaving examinations.

- To investigate equality of opportunities to schooling in terms student selection, composition and parental background.

- To explore conditions under which both public and private primary schools operate in rural and urban contexts. 
The expansion of private schools as well as public schools in Ethiopia is very significant. In 2012/13, there were a total of 30,534 primary schools out of which $7 \%$ were private in the nation (MOE, 2012/13). However, these dual systems are often perceived to have different standards. Usually it is claimed that the standards of private primary schools are better than the public schools. Nevertheless, these claims and perceptions have not so far been studied and ascertained. Thus, this study will contribute towards a better understanding of how these schools are faring in the process of national development.

\section{Public and Private Schools: Nature, Performance and Conditions of Work}

The variation of public and private schools has been discussed in various studies (see Arakelyan, 2005, Bray, 1996, OECD, 2012, Kitaev,1999, Walberg and Burst, 2003). Commonly, these studies agree that public schools are state or government schools mandated for or offered to all children by the government. State education is inclusive and it is organized and operated by government agencies. Private education, on the other hand, refers to any type of formal school which is outside the public education system (Kitaev,1999). The reasons for privatization are different in different countries, but dissatisfaction with the services provided by government institutions, access and coverage, quest for good quality, profit- making and the need to reduce pressures upon existing schools are some of the major rationales. Different forms of privatization are discussed in Arakelyan (2005), Bray (1996), and Walberg and Burst (2003), but Kitaev (1999) identifies five types of private education in Sub-Sahara Africa: community, religious, spontaneous (bush), profit-making and expatriate private schools. For the purpose of this study, public schools refer to government primary schools whereas private schools refer to all non-government primary schools.

The performance of private and public schools has been a subject to analysis in a large number of studies (see Jimenez, Lockheed and Paqueo, 1991; NAEP, 2006; Bohlmark and Lindhal, 2008;Dronkers and Robert, 2003). Most of these studies measure school performances using academic achievement in given subjects at a given grade/s. Results from these studies are similar. Students from private schools achieved more than students in public or government schools.

Reports on the possible causes of differences in school effectiveness are enormous (see Sammons, Hillman and Morti more, 2000, Schreens and Bosker,1997, Teddle and Reynolds, 2000, Stockard and Mayberry,1992, Dronkers and Robert, 2003, Temu, 1995).Typically these studies list variables that have significant influence on students learning. More recently, an exhaustive review of literature by Sammons, Hillman and Mortimore (2000) has summarized the following eleven main factors: professional leadership, shared vision and goals, learning environment, focus on teaching and learning, purposeful teaching, high expectations, positive reinforcement, monitoring progress, pupil rights and responsibilities, home-school partnerships and learning organization.

With particular reference to the possible conditions that explain the differences in effectiveness between public and private schools, a study by Dronkers and Robert (2003) included the following conditions: differences in student characteristics and school composition, deliberate school choice, different conditions for teaching-learning and school administration, different school climates and stronger core curriculum. Similarly, Chanand Tan (2008) reviewed factors that influence the effectiveness of private schools versus public schools from practice. They say that reputation of academic programs, school financial support systems, school size, class size, quality of teachers, level of education, special needs education, student admissions, cost, support service, religious affiliation, location, demographic characteristics of students, governance, and teachers impact and perception are the most important factors.

\section{Human Capital, Modernization and School Effectiveness Perspectives}

The summaries of human capital and modernization theories as well as the criticisms of the two approaches are given in Fagerlind and Saha (1989). Accordingly, it is mentioned that human capital theory is rested on the assumption that formal education is highly instrumental and even necessary to improve the production capacity or economic development of a population. In short, Fagerlind and Shaha (1989) note that human capital theory argues that an educated population is a productive population and it must be viewed not only as a productive investment, but also as a provider of skilled labor force necessary for industrial and economic growth.

According Fagerlind and Saha (1989), modernization is a sociological theory which argues that in order for a society to become modern (to develop economically and socially), it must be composed of 
a modern population, meaning having modern values, beliefs and behavior. For modernization theorists, there are causal links between five set of variables: modernizing institution, modern values, modern behaviors, modern society and economic development. Further, Fagerlind and Saha (1989) note that modernization perspectives assert that the creation of modern values can be the result of human planning and that particular social institutions are of extreme importance for their emergence, for example, the socialization which takes place in families, schools and factories.

Like human capital and modernization theories, school effectiveness studies are based on the assumption that school matters in students learning (scholastic achievement) as opposed to the view that home background matters more than schools (see Temu, 1995). However, school effectiveness perspectives realize that all schools are not equally effective and some are more effective than others. As Sammons, Hillman and Mortimore (2000) indicate, many variables or conditions affect the extent to which schools provide the necessary learning of students in terms of academic performance. In this study, student learning is measured by the results of the Regional School Leaving Certificate Examinations. The operational definitions of conditions under which schools in Ethiopia operate are based on the guideline provided by the Ministry of Education, but we focus only on few of them for the purpose of this paper.

\section{EDUCATION AND DEVELOPMENT IN ETHIOPIA}

The emergence of modern education in Ethiopia has its background in political and religious justifications than national development. Tekeste Negash (1990) indicates that the first modern school, Menilik II school, was created for training Ethiopians knowledgeable in European languages since the possession of such skills was considered vital for the country's sovereignty. McNab (1989) refers to the introduction of missionary schools for religious education in some parts Ethiopia before the modern state education made its entry.

The thinking that linked education to national development in Ethiopia took shape in the 1920s. Negash (1990) quotes Regent Taffari Mekkonnen's (later Emperor Haile Selassie I) speech of 1928 to argue that from this period onwards, the modern school was considered as an institution which possesses the mysterious key to rapid development. Negash (1990) further argues that after the fall of the imperial regime, the Post-Revolution sate accepted the challenge of expanding the education sector on the assumption that education held the key to the country's development.

The emergence of the Federalist Government replacing the post-revolutionary state has even brought the significance of education for development to its new height. Ethiopia's national development strategy under the Federal Government, known as Agricultural-Development- Led- Industrialization or ADLI (MOE, 2011), stressed that the essence of national development is to transform Ethiopia into a middle income country by extricating it from poverty by 2025. In this process, the use of science and technology and modern innovations are considered as vital instruments of change (MOE,2010). Following these directive, Ethiopia's Ministry of Education geared its sector wide implementation strategies known as ESDPs to improving the overall level of general education of the population on the one hand, and to Science and Technology Education on the other. For instance, ESDP IV (MOE, 2010:11) states this role of education as follows:

Achieving the vision of transforming Ethiopia into a middle-income country in 2025 demands transformation of the economy through application of science and technology as instruments to create wealth. In line with the key priorities of the current Growth and Transformation Plan, a large demand is expected for middle and high level human resources. It is therefore critically important to emphasize science and technology so as to produce capable citizens who can contribute to make the country competitive in the increasingly knowledge-based global economy. It has become mandatory for the education system to manifest overall improvement in sciences, mathematics, engineering and technology. This calls for a continued expansion and equitable access to high-quality general education with promising foundations in science and mathematics and special efforts to improve the science literacy level of the population.

While Ethiopia's strategy for science and technology education is obvious, the above quotation also indicates that the country is mindful of equity in the expanding system. The fact that a large majority of the Ethiopian population lives in rural areas and in fairly dispersed communities poses specific demands for both spreading education and ensuring equitable access. 


\section{RESEARCH Methodology}

A multi-method research approach with case study and survey perspectives was adopted (see Brewer and Hunter, 1989). The case study approach provided holistic perspectives for the two types (cases) of schools (private and public) to be studied in-depth (see Merriam, 1998). The survey approach directly provided quantitative data from larger population of selected schools (see Dane, 1990). From case studies, rich qualitative data were acquired which served to provide information for the interpretation of findings and explore additional prospects not covered by the quantitative data. To the extent that the study explores two cases of schools in the local context along the dimensions given in the frame of analysis, it is comparative.

By the time this study was conducted at the end of 2012/13, the total number of government primary schools in Ethiopia was 21, 734. In the same year, there were 1,620 private primary schools. Of these 34 public and 34 private primary schools, which served rural communities (in relatively similar areas) were purposefully selected. The study included 5 regions and 2 city administrations and the distribution of the number of schools within the selected size was proportional to the overall distribution of primary schools in each region.

The instruments used for data collection were questionnaires, interview guides, focus group interviews, school observation sheets and Grade 8 Regional Examination records. Sources of information were school directors, teachers, students, members of the school PTAs (Parents, Teachers and Students Associations) as well as school rosters. There were three types of questionnaires: school directors, teachers and students. Similarly, interview guides were prepared to obtain information from school PTA and school administration key informants as well as from teachers and students. Grade 8 National/Regional Examination Records were used in order to collect student achievement results from school rosters. School observation sheets were also used for independent observations.

A total of 1,260 respondents participated in the study. The total number of respondents who provided information through questionnaires was 1082 and those who participated in focus group and individual interviews was 178 . The interviewees were selected for the purpose of obtaining rich information and individuals were selected as key - respondents having adequate knowledge and experience in their respective schools.

Field work involved the collection of data from five regional states and two city administrations as planned. Prior to this process, however, instruments of data collection were pre-tested in 2 schools (1 Public and 1 Private). The pre-testing of instruments helped to determine the appropriateness of the instruments as well as the time required to administer them.

Given the scope and coverage of the study, it was necessary to recruit and use additional assistant researchers. Prior to their deployment as data collectors, field assistants were provided with both theoretical and practical training. To get access to target schools and respondents, the Ministry of Education (MOE) has written letters to relevant Regional Educational Bureaus (REBs). The Regional Educational Bureaus in their turn cooperated in writing letters to District (Woreda) Education Bureaus. Woredas (Districts) supported in the selection of schools and introducing researchers to schools by writing letters. Data collection in schools took place in phases and collection of school rosters covered a period of five years. Quantitative data from responses to questionnaires were analyzed using appropriate tools with the SPSS. Qualitative data were analyzed using categories \& narratives either independently by themselves or to support and crosscheck the quantitative data.

\section{MAJOR Findings OF THE STUdY}

\subsection{Student Academic Achievement in Grade 8 Regional Examinations}

Primary school students take state (regional) examinations in 8 subjects at the end of primary education in Grade 8 in Ethiopia. Thus, student achievement resultsover five years (2006-2010)were collected from most of the schools using a format prepared for this purpose. The objective of this exercise was exploring the variations in effectiveness of schools in providing the necessary knowledge, skills and attitudes at this level of education as desired by the official curriculum. Final results of all the eight subjects were included to ensure that comprehensive information is collected. The Ethiopian Education and Training Policy document (MOE, 1994b) states that students need to earn at least $50 \%$ in order to get promotion from grade to grade. In this case, results were calculated from 60 points and $50 \%$ would mean 30 points. The following were the results obtained from the analysis of the data collected. 
Table1. Student Academic Achievement in Grade 8 Regional Examinations in public and private schools

\begin{tabular}{|c|c|c|c|c|c|c|}
\hline \multirow[b]{3}{*}{ Subjects } & \multicolumn{6}{|c|}{ School Type } \\
\hline & \multicolumn{3}{|c|}{ Private } & \multicolumn{3}{|l|}{ Public } \\
\hline & Mean & St.Dev. & Total N & Mean & St. Dev. & Total N \\
\hline English & 37.04 & 6.97 & 156 & 23.83 & 3.39 & 154 \\
\hline Physics & 34.74 & 7.13 & 156 & 25.24 & 5.61 & 154 \\
\hline Chemistry & 36.25 & 6.56 & 156 & 26.32 & 5.45 & 154 \\
\hline Biology & 38.09 & 7.24 & 156 & 28.34 & 6.46 & 154 \\
\hline Math & 29.79 & 7.89 & 156 & 21.40 & 5.28 & 154 \\
\hline So.Science & 36.46 & 6.35 & 156 & 28.42 & 4.73 & 154 \\
\hline Civics & 45.83 & 4.24 & 156 & 40.32 & 7.53 & 154 \\
\hline Mother Tongue & 39.97 & 3.83 & 156 & 36.65 & 9.22 & 154 \\
\hline Average & 36.92 & 5.54 & 156 & 28.68 & 4.16 & 154 \\
\hline
\end{tabular}

Table 1 shows that private schools meet the minimum standards set by the Education and Training Policy (ETP) for promotion of students from grade to grade while public schools don't meet those standards. Private schools scored about 37 mean points while public schools scored about 29 mean points. In both school types, students scored least in mathematics and their highest average mean scores were in civics. This fact is consistent with findings in the literature which assert that students in private schools score more than students in public schools in examinations.

Focus group discussions with teachers indicated that there are recognitions of differences in student performance among schools. For instance, in one of the private schools in Oromia region teachers described student achievement as "...there is no talk of pass or failure in our school" while teachers in government school in the same region said "...our students are not among the highest achievers... and the academic achievement of our Grade 8 students is weaker in relation to other schools". These focus group discussions indicated some perceived reasons why some schools are better than the others. In private schools teachers' competence and commitment, parental follow up and high socio economic status, and availability of facilities where mentioned whereas in public schools, low parental support, low teacher quality, preoccupation of teachers by other things than instruction, low student motivation, lack of focus $\mathrm{n}$ student achievement were pointed out. This finding challenges both human and modernization theories which consider schools as sources of production skills and behaviors for all students without distinction. It concurs with school effectiveness perspectives which assert that some schools can be more effective than others.

\subsection{Student Selection and Admission}

There is no doubt that student selection is one area of difference between private and public schools. The public school policy on selection of students is to accept all those who come to the school because it has commitment to educate all school age children. Just to see how this mechanism differs from private schools, a question was forwarded to school directors to report on how they select their students. They were given six alternatives from which to choose (entrance exam, interviews, entrance exam and lottery, entrance exams and interviews, interviews with criteria, directly without any criteria). Results are summarized in Table 2.

Table2. School Directors' Responses about Student Selection

\begin{tabular}{|l|l|l|}
\hline \multirow{2}{*}{ Selection practices } & School Type & Public \\
\cline { 2 - 3 } & Private & $(4) 12 \%$ \\
\hline Entrance exam & $(9) 30 \%$ & $(2) 6 \%$ \\
\hline Entrance exam \& interview & $(13) 43 \%$ & $(0)) \%$ \\
\hline Entrance exam \&lottery & $(4) 13 \%$ & $(6) 17 \%$ \\
\hline Interviews & $(4) 13 \%$ & $(3) 9 \%$ \\
\hline Interviews \& with criteria & $(0) 0 \%$ & $(19) 56 \%$ \\
\hline Directly without criteria & $(0) \%$ & $(34) 100 \%$ \\
\hline & $(30) 100 \%$ & \\
\hline
\end{tabular}

While $56 \%$ of public schools directors reported that students are admitted directly without any criterion, majority of the private schools $(43 \%)$ indicated that they give entrance exams and interviews. The rest of the public-school directors indicated that they use single criterion like an interview, or a combination of entrance exams and interviews. What is interesting is the fact that public schools are adopting the characteristics of private schools because they exercise the selection of 
students although they are not supposed to. Selection of students implies checking upon student's background knowledge to improve their own image of academic effectiveness at the expense of student opportunities to schooling.

\subsection{Student Composition}

Grades 6 to 8 students from both types of schools were requested to fill their age and sex in the prepared questionnaire. The government policy states that students enter a school at age of 7. Thus, the expected age range for Grades 6 to 8 students is between 13 and 15. Similarly, gender equity is one of the main goals of Ethiopian education and it was important to see how these schools fare in this respect.

Table3. Age and Sex Composition of Students

\begin{tabular}{|l|l|l|l|l|l|}
\hline \multirow{2}{*}{ School type } & Age & Less than 13 years & $13-15$ Years & More than 15 years & Mex \\
\hline Private & $(50) 28 \%$ & $(117) 66 \%$ & $(9) 6 \%$ & $(95) 52 \%$ & Female \\
\hline Public & $(17) 9 \%$ & $(118) 61 \%$ & $(57) 30 \%$ & $(102) 52 \%$ & $(94) 48 \%$ \\
\hline
\end{tabular}

The table above shows that majority of students in both private (66\%) and public (61\%) schools are in the expected age limits for primary education. However, private schools have more appropriate age limits of students in their grades. It is interesting, however, to see that in both types of schools, the proportion of males and females is $52 \%$ to $48 \%$.

\subsection{Student Family Background}

Students were asked to indicate their family educational background which was categorized into five stages or criteria. As a proxy indicator, the educational level of parents relates to many other socioeconomic wellbeing of the student. Educated parents have value for their child's education, economic income to support their children and expertise to support schools.

Table4. Educational Background of Student Parents by School Type

\begin{tabular}{|l|l|l|l|l|}
\hline Categories & Father's Education & \multicolumn{2}{l|}{ Mother's Education } \\
\hline & Private & Public & Private & Public \\
\hline Cannot Read and Write & $(4) 2 \%$ & $(29) 15 \%$ & $(11) 6 \%$ & $(69) 35 \%$ \\
\hline Can Read and Write & $(12) 7 \%$ & $(53) 28 \%$ & $(26) 14 \%$ & $(44) 22 \%$ \\
\hline Completed Primary School & $(18) 10 \%$ & $(36) 19 \%$ & $(24) 13 \%$ & $(36) 18 \%$ \\
\hline Completed Secondary School & $(34) 19 \%$ & $(19) 10 \%$ & $(51) 28 \%$ & $(23) 12 \%$ \\
\hline Completed Higher Education & $(111) 62 \%$ & $(53) 28 \%$ & $(70) 38 \%$ & $(24) 12 \%$ \\
\hline Total & 179 & 190 & 182 & 196 \\
\hline
\end{tabular}

The above table shows that the educational background of majority of children's parents in private schools is higher education even when schools are located in predominantly rural communities. Accordingly, $62 \%$ of children in private schools said that their fathers have completed higher education while $38 \%$ of the children in these schools have mothers who have completed higher education. In one boarding private school, deep in the country side in Oromia region, interviews with key informants indicated that the school gets its students from urban areas (as far as the capital city) because some affording parents want their children to have good education and moral character (discipline) in such a school.

In public schools about $62 \%$ of students said that their father's education is either primary education or less than primary education. In these schools, only $12 \%$ of students said that their mothers have completed higher education. The above data shows that the educational level of the parents of public school students is less than the level of education of private school students. Thus, it is hardly surprising that these parents are able to afford the necessary costs for the education of their children.

\subsection{Access to Classrooms and Teachers}

Directors were asked to indicate the section-student ratio and teacher-student ratio as proxy indicators for school equity, efficiency and quality respectively. Too high section-student ratio shows overcrowdedness (inadequate access to or overuse of facility) whereas too high teacher-student ratio shows reduced contact time. 
Teshome Nekatibeb Begna

Table5. Average Section-Student and Teacher-Student Ratios

\begin{tabular}{|l|l|l|l|l|}
\hline \multirow{2}{*}{ Year } & Average section-student ratio & \multicolumn{2}{l|}{ Teacher-student ratio } \\
\cline { 2 - 5 } & Private & Public & Private & Public \\
\hline $2007 / 08$ & 47 & 62 & 44 & 47 \\
\hline $20008 / 09$ & 58 & 65 & 41 & 44 \\
\hline $1009 / 10$ & 47 & 56 & 41 & 41 \\
\hline
\end{tabular}

The average section -student ratio (i.e. the average number of students in one section) is certainly higher in public schools than in private schools. In Ethiopia the average standard set for section -pupil ratio is 1:45 in primary education and the above table shows that classes are larger than the standards in both types of schools, but it is more in public schools than the private ones. On average, the teacher-student ratio does not show significant variations between the two groups of schools and it is also less than the national standard which is 1:50.

\subsection{Teacher Qualifications}

The country's education policy considers teachers as important parts of the learning environment. The standards of the Ministry of Education determine that the minimum requirement for teachers to teach in primary schools is a teacher education- college- diploma. Sampled teachers were asked to indicate their qualifications from three alternatives: diploma, certificate and other. Table 6 shows that 249 $(81 \%)$ in public schools and $136(54 \%)$ in private school have diploma. The Table also shows that 41 (13\%) public teachers and $22(9 \%)$ private teachers have certificate.

Table6. Teachers' Qualification as Reported by Sampled Teachers

\begin{tabular}{|l|l|l|}
\hline \multirow{2}{*}{ Qualification } & School Type \\
\cline { 2 - 3 } & Private & Public \\
\hline Diploma & $(136) 52 \%$ & $(249) 81 \%$ \\
\hline Certificate & $(22) 9 \%$ & $(41) 13 \%$ \\
\hline Other (degree \& above) & $(93) 37 \%$ & $(16) 5 \%$ \\
\hline Total & 251 & 306 \\
\hline
\end{tabular}

Table 6 above also shows that about $37 \%$ of the private school teachers have indicated other qualifications (university degree and above) compared to 5\% of teachers in public schools. All in all, students in private schools have more access to more qualified teachers' than students in public schools.

\subsection{School Environment and Attractiveness}

The attractiveness of private and public school environments was explored using the given criteria in Table 7. Results indicate that private schools excel in having safe compounds, convenient classrooms, drinking water, playing ground, places for eating lunch and separate toilets (see the cover page for contrast). Public schools excel in controlling corporal punishment and providing cafeteria services. The fact that corporal punishment is still taking place in Ethiopian primary schools is very shocking.

Table7. School Attractiveness by School Type

\begin{tabular}{|l|l|l|l|l|}
\hline \multirow{2}{*}{ Attractiveness } & \multicolumn{4}{|l|}{ School Type } \\
\cline { 2 - 5 } & Private & Public & \multicolumn{2}{l|}{} \\
\cline { 2 - 5 } & Yes & $(0) 0 \%$ & Yes & No \\
\hline Fenced for safety & $(30) 100 \%$ & $(33) 92 \%$ & $(3) 8 \%$ \\
\hline Convenient classrooms & $(27) 96 \%$ & $(1) 4 \%$ & $(34) 94 \%$ & $(2) 6 \%$ \\
\hline Convenient offices & $(26) 96 \%$ & $(1) 4 \%$ & $(29) 81 \%$ & $(7) 19 \%$ \\
\hline Drinking water & $(26) 100 \%$ & $(0)) \%$ & $(32) 89 \%$ & $(4) 11 \%$ \\
\hline Playing grounds & $(21) 78 \%$ & $(6) 22 \%$ & $(23) 66 \%$ & $(12) 34 \%$ \\
\hline Places for lunch & $(22) 82 \%$ & $(5) 18 \%$ & $(10) 29 \%$ & $(25) 71 \%$ \\
\hline Corporal punishment & $(4) 15 \%$ & $(23) 85 \%$ & $(3) 9 \%$ & $(32) 91 \%$ \\
\hline Toilets for males \&females & $(27) 96 \%$ & $(1) 4 \%$ & $(30) 83 \%$ & $(6) 17 \%$ \\
\hline Cafeteria services & $(18) 69 \%$ & $(8) 31 \%$ & $(29) 81 \%$ & $(7) 19 \%$ \\
\hline
\end{tabular}

Corporal punishment may cause students physical and psychological harm and it is a violation of the child's rights. It creates fear among children and it can cause dropouts and wastage in education.

Observations have shown that public schools have deficiencies in the organization of their learning environments. For instance, the environment in a public school around Bahir Dar in Amhara state is extremely sub-standard in that it lacks neatness, windows, doors, electricity and located in a smelly 
area. Another school in SNNPR, (Yekatit 25) is built on swampy area and water springs from under the classroom floors. Due to this, school buildings and classroom floors are consistently cracking. At the same time, there are private schools like Bahir Dar Academy, Hawassa SOS and Addis Cathedral which are directly opposite to the public schools mentioned earlier.

\subsection{Access to Basic Learning Facilities}

Another interesting item which asked the details of available materials in schools and their sufficiency was included in the school head's questionnaire. Results in Table 8 indicate that in majority of private schools, school facilities are available and sufficient with the exception of clinics and access to the internet. In public schools insufficiencies, have been reported in many areas: classrooms, teaching materials, clinics, libraries, books in the libraries, laboratories and computers. In majority of the public schools, clinics, laboratories and laboratory equipment, computer and internet are not available. This finding is consistent with MOE data (2012/13) which shows that only $21 \%$ and $43 \%$ of schools have clinics and libraries that national level.

Table8. Availability and Sufficiency of school materials by school type

\begin{tabular}{|l|l|l|l|l|l|l|l|l|}
\hline \multirow{5}{*}{} & \multicolumn{9}{l|}{ School Type } \\
\cline { 2 - 9 } & Private & \multicolumn{3}{l|}{ Public } \\
\cline { 2 - 9 } & Yes & No & Sufficient & Insufficient & Yes & No & Sufficient & Insufficient \\
\hline Clinic & $(6) 22 \%$ & $(16) 59 \%$ & $(0) 0 \%$ & $(5) 19 \%$ & $(1) 3 \%$ & $(33) 92 \%$ & $(0) 0 \%$ & $(2) 6 \%$ \\
\hline Library & $(13) 45 \%$ & $(0)) \%$ & $(11) 38 \%$ & $(5) 17 \%$ & $(9) 25 \%$ & $(2) 7 \%$ & $(5) 14 \%$ & $(20) 56 \%$ \\
\hline $\begin{array}{l}\text { Books in the } \\
\text { library }\end{array}$ & $(12) 41 \%$ & $(0) 0 \%$ & $(10) 35 \%$ & $(7) 24 \%$ & $(6) 17 \%$ & $(2) 6 \%$ & $(7) 19 \%$ & $(21) 58 \%$ \\
\hline Laboratories & $(12) 41 \%$ & $(4) 14 \%$ & $(9) 31 \%$ & $(4) 14 \%$ & $(6) 17 \%$ & $(14) 39 \%$ & $(2) 6 \%$ & $(14) 39 \%$ \\
\hline Computers & $(14) 48 \%$ & $(3) 10 \%$ & $(5) 17 \%$ & $(7) 24 \%$ & $(6) 17 \%$ & $(11) 31 \%$ & $(4) 11 \%$ & $(15) 42 \%$ \\
\hline Internet & $(9) 35 \%$ & $(11) 42 \%$ & $(4) 15 \%$ & $(2) 8 \%$ & $(4) 11 \%$ & $(26) 72 \%$ & $(4) 11 \%$ & $(2) 6 \%$ \\
\hline Electricity & $(20) 67 \%$ & $(0) 0 \%$ & $(10) 33 \%$ & $(0) 0 \%$ & $(17) 47 \%$ & $(0) 0 \%$ & $(14) 39 \%$ & $(5) 14 \%$ \\
\hline
\end{tabular}

What these findings in Table 8 suggest is that private schools are more equipped than public schools. Interviews with teachers in groups show that facilities within the private sector are well organized and there are very insignificant differences or variations among schools. However, in the public sector, schools reported from "almost empty" to availability of some facilities. The presence or absence of these facilities is important because it affects the quality, efficiency, access and equity of schooling. School facilities are tools to attract students in general and girls in particular.

\subsection{Curriculum Alignment}

In focus group discussions teachers were asked if their curricula have alignment with the national curriculum. In this respect schools reported that they follow the national curriculum, but private schools reported that they have additional activities for students. For instance, teachers in one private school in Addis Ababa said:

We use both the national curriculum including text books, subjects, period allocations etc. and have additional arrangements like worksheets, \& additional materials. Capacity in English language is developed in such a way that Grammar, Reading Comprehension and Spoken English are taught separately. In science we have a well-developed and standardized laboratory which is used by students. Demonstration corners are also available in other rooms.

A PTA chairman of a private school in SNNPR, around Hawassa said the following similar practice:

The curriculum is mixed, both foreign and national. The kids develop more confidence and versed in both curricula. It keeps them busy, because the load is heavier. They learn the foreign curriculum with English and this would develop their language skills....

Public schools are mainly preoccupied with the formal curriculum guidelines, but have challenges with putting it to practice. In one public school in Addis Ababa, a teacher said the following:

We follow MOE guidelines in the teaching-learning process. Active learning as a methodology is not used as such because parents insist that too much assignment or home work will take the time students need to work. Teachers have got training, but to apply it is also too difficult for the teacher. 
The same view was echoed in one public school in SNNPR around Yirgalem:

Students are not interested in learning and to improve their own results. When the school prepares tutorials and request students to come to attend no one shows up for tutorials.

Teachers in one public school in Addis Ababa reported that they overcome challenges in implementing the national curricula in different ways: flexible teaching schedule, intensive use of textbooks, community training and continuous assessment. The difference here is, thus, private schools use other inputs in addition to the national curriculum while public schools struggle to put the national curriculum into practice.

\subsection{Leadership and Management}

Focus Group discussions with members of Teacher-Parent-Student Associations have produced detailed information on the governance and leadership administration of schools. The information summarized in Table 9 tells that private and public schools have more differences than similarities in school governance and leadership. These schools are similar in communications of school values, decentralized or participatory decisions making and clarity of administrative structures and in encouraging initiatives by teachers.

However, Table 9 also shows that the leadership of private schools differs from public school in its achievement orientation. For instance, in both types of schools leaders communicate school values and programs, but private schools turn communications more into actions. Similarly, Private schools are more focused on student learning, achievement, promotion and success because they have to attract the market. Private schools are less prone to teacher professional development than public schools, perhaps because they require high level expertise and experience right from the start at recruitment.

Table9. School governance and leadership in private and public schools

\begin{tabular}{|c|c|c|}
\hline Characteristics & Private & Public \\
\hline Similarities & $\begin{array}{ll}\text { - } & \text { Induction/ orientation for beginning } \\
\text { - } & \text { Deachers } \\
\text { - } & \text { Tecisions at lower level management } \\
\text { - } & \text { Elaborate administrative structure }\end{array}$ & $\begin{array}{ll}\text { - } & \text { Orientation for beginning teachers } \\
\text { - } & \text { Decentralized and shared } \\
\text { responsibility } \\
\text { - } \quad \begin{array}{l}\text { Teachers are autonomous for } \\
\text { initiatives }\end{array} \\
\text { - } \begin{array}{l}\text { Elaborate planning, organization and } \\
\text { evaluation of activities }\end{array}\end{array}$ \\
\hline Differences & $\begin{array}{ll}\text { - } & \text { Persuasive communication seconded by } \\
\text { - } & \text { action } \\
\text { - } & \text { development } \\
\text { - } & \text { Focus on improvement of students } \\
\text { - } & \text { learning } \\
\text { - } & \text { Adequate school facilities \&materials } \\
\text { - } & \text { High retention and stability of principals } \\
\text { - } & \text { Reasonable remuneration and fringe } \\
\text { - } & \text { benefits } \\
\text { - } & \text { Principals at work }\end{array}$ & $\begin{array}{ll}\text { - } & \text { Open discussion, but little action } \\
\text { - } & \text { Focus on teachers' professional } \\
\text { - } & \text { Fevelopment } \\
\text { - } & \text { Schoon on access and school order } \\
\text { - } & \text { Preoccupied with fulfilling facilities } \\
\text { - } & \text { High turnover of principals } \\
\text { - } & \text { Lack of incentives for teachers } \\
\text { - } & \text { Less control and supervision } \\
\text { - } & \text { Principal out of school }\end{array}$ \\
\hline
\end{tabular}

Obviously, the leadership in public school focuses not only in admitting as many students as possible, but also in coordinating the entrants. Adequate facilities, access to experienced principals and motivated teachers are more prevalent in private schools than in public schools. Private ownership also involves heavy supervision and control in schools than in public ones. Principals in private schools spend more of their time at work than principals in public schools.

\section{Summary}

Findings from the current study indicate multidimensional differences between private and public schools. Primarily, private schools are more effective in student learning achievements as compared to public schools. Secondly, private schools select their own students by checking their background knowledge whereas most public schools do not use any criteria to select students. However about $44 \%$ of public schools are involved in student selection using one or some criteria, and it is a worrying 
trend. Third, the work environments provided by private schools excel in almost all directions except for corporal punishment. Classrooms are less crowded and teachers are more qualified in private schools as compared to public schools.

Both groups of schools follow the national curriculum guidelines. However, private schools have reported that they put additional demands to students whereas public schools are totally occupied with the implementation of the national curriculum requirements. Private schools also provide more learning facilities than public schools.

Majority of students in both private school and public schools are within the expected age limits, but it is more so in private schools than in public schools. Both schools have similar proportion of female to male students. Majority of children in private schools have fathers and mothers who have completed higher education whereas majority of children in private schools have fathers and mothers who have an educational level of or less than primary education.

\section{Conclusions}

The expansion of public and private schools in Ethiopia reflects the commitment to the ideals in human capital and modernization theories to have an educated population for social and economic development. In this sense, both school types are partners in development. However, school effectiveness perspectives also apply in Ethiopia because both types of schools which are expected to provide similar learning opportunities and results differ in how much they perform these functions. Overall, private schools show that they provide more learning achievement and learning organization than public schools. While this finding is consistent with other findings, there is a clear implication for policy making in Ethiopia. Firstly, government schools need to be upgraded to be more equal with private schools. Otherwise, the inequality that is going to follow the current variations in effectiveness of schools won't produce desirable effects for the equitable development of the nation. Secondly, the mutation of public schools into private -like- schools needs to be controlled through government efforts. For instance, the admission of students using selection criteria leads to the denial of opportunities for children of the rural population in the public sector. Third, the government needs to exercise some control over private schools to maintain similar standards. Student learning cannot be totally left to the privileged in the private sector and the government needs to work out how private schools can be accessible to children from different backgrounds. Moreover, some unacceptable practices like corporal punishment need to be ended in private schools. Overall, both types of schools need to partner in creating social cohesion and transformation. This includes advancing similar values, curricula, culture and goals in order to create a more just society in Ethiopia.

\section{REFERENCES}

Addis Ababa University (AAU).(2008).University-Wide Strategic Plan 2008-13. Shaping the Future of a Flourishing Higher Education for Regenerating Nation. Addis Ababa: AAU.

Arakelyan. V. (2005).Privatization as a Means to Property Redistribution in Republic of Armenia and Russian Federation. Tampre: University of Tampre.

Bhola, H.S. (2011).Systems Theory Perspective on Education for Rural Transformation: In the Dialectic between Global Contexts and Local Conditions. In V. Chinapah (Ed.), Education for Rural Transformation (ERT) (pp. 3-11).Stockholm: Stockholm University.

Bohlmark, A., Lindhal, M. (2008). Does School Privatization Improve Educational Achievement? Evidence from Sweden's Voucher Reform. Bonn: Stockholm and Uppsala Universities. Discussion Paper.

Bray, M. (1996). Privatization of Secondary Education: Issues and Policy Implications. United Nations Educational, Scientific and Cultural Organization, Paris.

Brewer, J. and Hunter, A. (1989). Multimethod Research: A Synthesis of Styles. London: Sage Publishers, Inc.

Chan, D. and Tan, J. (2008). Privatization and the rise of Direct Subsidy Scheme Schools and Independent Schools in Hong Kong and Singapore. International Journal of Education Management, (22)6.464-487.

Central Statistical Authority (CSA). (2008). Ethiopian Statistical Abstract. Addis Ababa: Government of Ethiopia.

Dane, F. C. (1990). Research Methods. California: Brooks/Cole. 
Dronkers, J. and Robert, P. (2003). The Effectiveness of Public and Private Schools froma Comparative Perspective. Florence: European University Institute.

Fagerlind, I. and Saha, L. (1989). Education and National Development: A Comparative Perspective. Oxford: Pergamon.

Freeman, P. and Mohamedbhai, G. (2011). Reform and Expansion of Research Training at Addis Ababa University. Assessment Report of Progress under Agreement 2009-2011, Sida Block Grant. Addis Ababa: AAU

Jimenez, E., Lockheed, M.E., and Paqueo, V. (1991).The Relative Efficiency of Private and Public Schoolsin Developing Countries. The World Bank Research Observer, 6(2). 205-218.

Kitaev, I.(1999). Private education in sub-Saharan Africa: A re-examination of theories and concepts related to its development and finance. Paris: UNESCO.

McNab, C. (1989). Language Policy and Language Practice: Implementation Dilemmas in Ethiopian Education. Stockholm: Stockholm University.

Merriam, S.B.(1998). Qualitative Research and Case Study Applications in Education. San Fransisco: Jossey-Bass Publishers.

Ministry of Education (MOE). (2012/13). Education Statistics Annual Abstract. Addis Ababa: Author.

- (1994a). Education Sector Strategy. Author.

- (1994b). Education and Training Policy. Author.

- (2009). Primary Education Measurement Standard. Addis Ababa: Author.

- (2010). Education Sector Development Program IV (2010/11-2014/15): Program Action Plan. Addis Ababa: Author.

NAEP (2006). The Nation's Report Card: Student Achievement in private Schools. Results from NAEP 2000-2005. Washington. D.C.:U.S. Department of Education, National Center for Education Statistics.

Negash, T. (1992). The Crises of Ethiopian Education: Some Implications for Nation -Building. Uppsala: Uppsala University.

OECD(1989). Public and Private Schools: How management and funding relate to their socioeconomic profile, OECD publishing. http://dx.doi.or/10/1787/9789264175006-en.

Scheerens, J. and Bosker, R. (1997). The Foundations of School Effectiveness. Oxford: Pergamon Press.

Stockard, J. and Mayberry, M. (1992). Effective Educational Environments. London: Corwin Press, Inc.

Summons, P., Hillman, J., Mortimore, P. (1995). Key Characteristics of Effective Schools: A Review of School Effectiveness Research. London: London University.

Teddlie, C., \& Reynolds, D. (2000). The international handbook of school effectiveness research. London: Falmer Press.

Temu, E.B. (1995). Successful Schools in Tanzania: A Case Study of Academic and Production Programs Stockholm: Gotab.

Walberg, H.J. and Bast, J.L. (2003).Education and Capitalism: How Our Fear of Markets and Economics Improve American Schools. United Sates/CA: Hoover Institution Press Publications; no: 521 . 